\title{
ENFORCEMENT OF HEALTH LAW: THE LARGE SCALE SOCIAL LIMITATION IN INDONESIA VIEWED OF THE THEORY OF AL- MAQASHID ASY-SYAR'IYYAH"
}

\author{
Hidayatullah \\ Program Studi Ilmu Hukum, Fakultas Hukum Uniska MAB Banjarmasin \\ Jl. Adhyaksa, Jl. Kayu Tangi 1 Jalur 2 No.2, Sungai Miai, Banjarmasin \\ email: hidayatullah250879@gmail.com

\section{Nasrullah} \\ Program Studi Ilmu Hukum, Fakultas Hukum Uniska MAB Banjarmasin \\ Jl. Adhyaksa, Jl. Kayu Tangi 1 Jalur 2 No.2, Sungai Miai, Banjarmasin, \\ email: nas12.jm@gmail.com
}

\begin{abstract}
Abstrak: Beranjak dari mewabahnya pandemi Virus Corona (Covid-19) pada awal tahun 2020 termasuk di Indonesia, membuat umat manusia digoncang dengan berbagai kepanikan. Untuk menanggulangi wabah pandemi Covid-19, Pemerintah Indonesia menetapkan status kedaruratan kesehatan masyarakat dan memberlakukan kebijakan Pembatasan Sosial Berskalaa Besar (PSBB). Namun penegakan hukum kesehatan ini mengakibatkan polemik baru bagi masyarakat, terutama bagi kaum muslimin Indonesia yang tidak bisa beribadah secara berjamaah di masjid atau tempat ibadah lainnya. Tujuan penelitian ini untuk menganalisa kebijakan PSBB yang diterapkan Pemerintah dari sudut pandang alMaqashid asy-Syar'iyyah. Penelitian ini merupakan penelitian hukum dengan metode studi kepustakaan dan dengan pendekatan yuridis normatif. Dengan demikian, yang menjadi bahan hukum adalah regulasi terkait kebijakan PSBB yang diberlakukan oleh Pemerintah Indonesia. Adapun hasil penelitian menunjukan bahwa meskipun memiliki berbagai dampak dan konsekuensinya, namun secara teori al-Maqashid asySyar'iyyah kebijakan PSBB merupakan salah satu pilihan terbaik dalam rangka penanggulangan wabah pandemi Covid-19 di Indonesia.

Kata Kunci: Hukum Kesehatan, PSBB, Wabah Pandemi, Covid-19, alMaqashid asy-Syar'iyyah
\end{abstract}

\begin{abstract}
Starting from the outbreak of the Corona Virus pandemic (Covid-19) in the early 2020s including in Indonesia, humanity was shaken with a variety of panic. To cope with the Covid-19 pandemic outbreak, the Government of Indonesia established a public health emergency status and adopted a Large Scale Social Restrictions (LSSL) policy. However, this health law enforcement issues a new polemic for the society, for Indonesian Muslims who cannot worship in congregation in mosques or
\end{abstract}


other places of worship. The purpose of this study is to analyze the LSSL Policy that implemented by the government from the perspective of alMaqashid asy-Syar'iyyah. This research is a legal research with literature study method and normative juridical research. Thus, the legal material related to the LSSL policy imposed by the Government of Indonesia. Based on the results of the study showed that there are some differences and their consequences, but the theory of al-Maqashid asy-Syar'iyyah LSSL policy is one of the best choices in the framework of overcoming the Covid-19 pandemic outbreak in Indonesia.

Keywords: Health Law, LSSL, Pandemic outbreak, Covid-19, Maqashid Syar'iyyah

\section{INTRODUCTION}

In early 2020 the world was shocked by the pandemic outbreak of corona virus (Covid-19) which infected almost all countries. Even since January 2020 WHO had declared the world into a global emergency related to this virus, declaring it as a pandemic. Pandemic outbreak of Corona Virus Disease 2019 (Covid-19) continues to expand and increase, with the number of deaths and cases of infection more one million people so that it has a serious impact on various aspects of life, even unfortunately and it 's also until now there are no treatments, drugs, antivirals and Serum for Coronavirus Pandemic. ${ }^{1}$

${ }^{1}$ Fitri Sartina Dewi, 'Pedoman PSBB Corona Terbit, Ini Isi Lengkapnya', Berita, Kabar24.Bisnis.Com, (4 April 2020), https://kabar24.bisnis.com/ ead/20200404/15/1222527/ pedoman-psbbcorona-terbit-ini-isi-lengkapnya. Accessed on May 9th 2020.

2Yoseph Hary W, 'Hasil Penelitian 3 Transmisi Virus Corona Sampai Ke Indonesia, Ini Asal
Almost all countries in the world have been hit by the pandemic outbreak of Covid-19, including Indonesia. According to LBM post-doctoral researcher Eijkman, Pradiptajati Kusuma, several corona virus research samples in Indonesia all came from China and then traveled to many countries. But, it is not yet known whether the virus is carried by foreigners who go to a country then spread the virus or how, because until now researchers have mapped the virus origin based on the genetic standpoint of the virus. ${ }^{2}$ As in other countries in the world, the spread of Covid19 in Indonesia is increasing and expanding across regions and across countries which is also accompanied by an increase in the

Muasal COVID-19 Di Tanah Air', News, Jogja.Tribunnews.Com, (6 May 2020), https://jogja.tribunnews.com /2020/05/06/hasil-penelitian-3-transmisivirus-corona-sampai-ke-indonesia-ini-asalmuasal-covid-19-di-tanah-air?page $=4$. Accessed on May 9th 2020. 
number of cases. As of the initial spread, which was predicted in January $2020^{3}$ to as of May 9, 2020, this outbreak has claimed 13,645 positive cases with 959 fatalities. $^{4}$

Considering the serious impact caused by the outbreak caused by this infectious disease, protective measures are needed for the society in the midst of the massive spread and victims of Covid-19 in Indonesia. Therefore, based on consideration of people's safety, economy and social conditions and referring to Act Number 36 Year 2018 on Health Quarantine, the Government adoptes a phenomenal policy by imposing Large Scale Social Restrictions (LSSL). In Article 1 of Government Regulation No. 21 of 2020 on Large Scale Social Restrictions in the Framework of Accelerating Handling of Corona Virus Disease 2019 (Covid-19), it was explained that Large Scale Social Restrictions are restrictions on certain activities of residents in an area suspected of being infected with Covid-19 such in a

${ }^{3}$ Ahda Bayhaqi, 'Virus Covid-19 Diprediksi Mulai Masuk Indonesia Pada Januari 2020', News, Merdeka.Com, (May 2020), https://www.merdeka.com/ peristiwa/ viruscovid-19-diprediksi-mulai-masuk-indonesiapada-januari-2020.html. Accessed on May 9th 2020.

${ }^{4}$ Task Force for the Acceleration of Handling Covid-19, 'Data Sebaran, Update Terakhir per 09 Mei 2020', News, Covid19.Go.Id, (May 2020), https://covid19.go.id/. Accessed on May 9th 2020.

5 Indonesia Government, 'Government Regulation No. 21 of 2020 on Large Scale Social way to prevent the possible spread of Covid-I9. ${ }^{5}$ Then The Government Regulation was followed up by Minister of Health Agus Terawan Putranto by issuing Large Scale Social Limitation Guidelines in the framework of Accelerating the Management of Corona Virus Disease 2019 (Covid-19) contained in Minister of Health Regulation No. 9 of 2020, on April 3, $2020{ }^{6}$ Regarding the LSSL implementation, Oscar Primadi, Secretary General of the Ministry of Health, said a number of things including that the restrictions include safeguarding schools and workplaces, restrictions on religious activities, restrictions on activities in public places or facilities, restrictions on socio-cultural activities, restrictions on modes of transportation, and restrictions other activities specifically related to defense and security aspects. ${ }^{7}$ About restrictions on religious activities, Oscar Primadi explained that restrictions on religious activities were in the form of religious activities carried out

Restrictions in the Framework of Accelerating Handling of Corona Virus Disease 2019 (Covid-19) Article 1'.

${ }^{\circ}$ Dewi, 'Pedoman PSBB Corona Terbit, Ini Isi Lengkapnya'.

${ }^{7}$ Hukumonline.com, 'Menkes Terbitkan Aturan Pedoman PSBB Penanganan Covid-19', News, Hukumonline.Com, (May 2020), https://www.hukumonline.com/berita/baca/ lt5e88 b1c22a471/ menkes-terbitkan-aturanpedoman-psbb-penanganan-covid-19/. Accessed on May 9 $9^{\text {th }} 2020$. 
at home and attended by limited families, by keeping everyone away. He emphasized that beyond that, religious activities were carried out in accordance with statutory regulations, and fatwas or views of official religious institutions which recognized by the government. ${ }^{8}$

The purpose of limiting the activities above is to limit the gathering of large numbers of people at a particular location. With various forms of social restrictions, the enforcement of health law is certainly felt by the Indonesian people is very burdensome because they are not allowed to carry out their daily routine normally. Especially for you Indonesian Muslims, this LSSL policy will definitely injures the implementation of daily worship activities, such as praying in congregation in mosques, prayer rooms, and other places of worship. Even Muslims in Indonesia are urged by the government to worship in their own homes. On March 16, 2020, the Indonesian Ulema Council (IUC) also issued a fatwa, one of which stipulates the legal provisions stating that everyone have to make efforts to maintain health and stay away from everything that could cause exposure to the disease, because it is a part of maintaining

${ }^{8}$ Ibid.

'Indonesia Ulema Council, 'Fatwa of Indonesia Ulema Council No. 14 of 2020 on Organizing Worship in Outbreak Situations of Covid-19', n.d. the main religious objectives (al-Dharuriyat al-Khams). ${ }^{9}$ Based on the description before, the authors are interested in researching the enforcement of this health law by discussing the Large Scale Social Restrictions Policy (LSSL) in Indonesia in terms of the rules of ushul fiqh, al-Maqashid asy-Syar'iyyah.

\section{Theory of al-Maqashid asy-Syar'iyyah}

In the language of al-Maqashid asy-Syar'iyyah consists of two words namely Maqâshid and Syarîah. The word Maqashid is the jama'a of the word maqshid which means the difficulty of what is intended or intended. ${ }^{10}$ Maqashid also means intent or purpose, which means to intend or intend. Maqashid means things that are desired and intended. ${ }^{11}$ While the word Syar'iyyah is a mashdar from the word syar 'which means something that is opened to take what is in it, and Syar'iyyah is a place visited by humans or animals to drink water. It also comes from the root words syara'a, yasyri'u, syar'an which means to start a job. ${ }^{12}$

The definition of Maqashid and Syar'iyyah mentioned above can explain the understanding of al-Maqashid asy-Syar'iyyah in terminology, namely the purpose or

${ }^{10}$ Ahsan Lihasanah, Al-Fiqh al- Maqâsid 'Inda alImami Asy-Syâthibi (Egypt: Dar al-Salam, 2018), 11.

${ }^{11}$ Ibnu Mandzur, Lisaan Al-'Arab (Kairo: Darul Ma'arif, n.d.), 3642.

${ }^{12}$ Hasbi Umar, Nalar Fiqib Kontemporer (Jakarta: Gaung Persada Press, 2007), 36. 
objectives of the Islamic law in Islamic sharia, this indicates that the al-Maqashid asySyar'iyyah closely related to wisdom and illat. ${ }^{13}$ According to Wahbah al-Zuhaili, alMaqashid asy-Syar'iyyah is the values and targets of shara' which it is implied in all or the largest part of its laws, which is seen as the objectives and secrets of shari'a, which are set by Shari' (Allah and the Prophet Muhammad) in every legal provision. ${ }^{14}$

Al-Juwaini argued that al-Maqâshid asy-Syar'iyyah is based on several pillars, as follows: ${ }^{15}$

1. Something that can be reasoned and understood its meaning so that it is interpreted into things that are primary (dharurab), such as sanctions of qisas prescribed to prevent humans from continuing bloodshed;

2. Something related to public intentions but does not reach the emergency stage, such as a lease transaction (ijarah) is prescribed because there is a need for people who do not have ownership capabilities;

3. Something not related to special dharurah or general intentions, but can achieve virtue and pleasure, such as cleansing the hadats and removing impurities;

${ }^{13}$ Ahmad ar-Raisuni, Naz̧hariyyât Al-Maqâshid Inda Asy-Syâtbibi (Rabat: Dâr al-Amân, 1991), 67.

${ }^{14}$ Wahbah al-Zuhaili, Ushûl Al-Figh al-Islâmi, II (Damaskus: Dâr al-Fikri, 1986), 225.
4. Something that is not based on things dharurah or hajjiyyah, but can be a supplement. This Maqâshid construction turned out to be the basis for contemporary scholars.

Ash-Shatibi divides Maqâshid into three categories based on the role and function of mashlahah on the survival of human beings. ${ }^{16}$ The three categories are: First, Maqâshid Dharuriyyat which in terms of language can be interpreted as an urgent or emergency need. So that in dharuriyyat needs, if these needs are not met, it will threaten the safety of humanity in the world and the hereafter. Maqâshid of this category includes: hifdz ad-din (Preserving Religion), bifdz an-nafs (Preserving the Soul), bifdz al'Aql (Preserving Intellect), bifd (Preserving Religion), and hifdz al-Mal (Preserving the Soul). Islamic Sharia is revealed to maintain the five points.

Second, Maqâshid Hajjizyat, which literally means secondary needs. If this need does not materialize it does not threaten safety, but it will experience difficulties. To eliminate these difficulties, in Islam there is a law rukhshah (relief), which is the law needed to ease the burden, so that the law can be implemented without feeling

${ }^{15} \mathrm{Al}$-Juwaini, Al-Burban Fi Ushul Figh, al-Wafa' Juz II (Tahqiq: Abd al-Ajim, 1918), 925.

${ }^{16}$ A. Djazuli, Fiqh Siyasab (Bandung: Prenada Media, 2003), 397. 
depressed and constrained. ${ }^{17}$ And finally, Maqâshid Tabsiniyyat, which means literally things that are perfect. This level of need is in the form of complementary needs. If these needs are not fulfilled, they will not threaten and not cause difficulties, ${ }^{18}$ and the level of these needs is in the form of complementary needs.

There are at least three methods used by scholars to understand al-Maqâshid asySyariyyah, namely among:

1. Considering the meaning of Dhabir Lafdz

The meaning of Dhabir is the understood meaning of what is written in religious lafdz, nash which is the main basis in knowing al-Maqâshid asy-Syar'iyyah. The inclination towards this method stems from the assumption that the maqasid alsyar'iyyah is abstract and cannot be known except through the guidance of God in the form of Dhabir Lafdz which is clear. ${ }^{19}$ So, the essential meaning of a text must not be turned away (pronounced) to the meaning of majazi, unless there are clear instructions from the shari'a maker, that what is meant is an implied meaning. ${ }^{20}$

${ }^{17}$ Yusuf al-Qardhawi, Fiqih Praktis Bagi Kehidupan Modern (Kairo: Makabah Wabah, 1999), 79.

18Ibid., 80.

${ }^{19} \mathrm{Abu}$ Ishâq al-Syâthibî, Al-Muwâafaqât Fi Usbûli Asy-Syarîah, Juz II (Beirut: Dar al-Kutub alIlmiyah, 2003), 297.

${ }^{20}$ Satria Effendi M. Zein, Metodologi Hukum Islam Dalam Amrullah Ahmad, Dkk, "Dimensi Hukum
This method was pioneered by Dawud ad-Dhahiri, a founder of the adDhabiriyah school. This school adheres to the principle that every legal conclusion must be based on its intrinsic meaning, the ultimate meaning of religious texts. According to this flow, the distortion of the meaning of the shari'ah texts to the meaning of majazi is a deviation that must be corrected. ${ }^{21}$

2. Considering the inner meaning and reasoning

The inner meaning is the meaning implied from a text of Islamic teachings. The inner meaning becomes the basis of consideration in knowing al-Maqâshid asySyar'iyyah is based on an assumption, that alMaqâshid asy-Syar'iyyah is not in the form of dhahir nor is it understood from the understanding indicated by dhahir lafdz of shari'a nash of Islam. But Asy-Syatibi called the group that adheres to this method as the Bathiniyah group, a group that intends to destroy Islam. ${ }^{22}$

3. Combining the meaning of dhabir, inner meaning and reasoning

Islam Dalam Sistem Hukum Nasional (Jakarta: Gema Insani Press, 1996), 123.

${ }^{21}$ Amrullah Ahmad, dkk., Dimensi Hukum Islam Dalam Sistem Hukum Nasional (Jakarta: Gema Insani Press, 1996), 123.

${ }^{22}$ Syamsul Bahri, Metodologi Hukum Islam, Cet. I (Yogyakarta: Teras, 2008), 110. 
This method of combination or combination aims to find out the alMaqâshid asy-Syar'iyyah by combining the two methods into one, with no damage to the meaning of dhahir, the meaning of meaning. Asy-Syatibi states that the consideration of the meaning of dhahir, inner meaning and the meaning of reasoning have a symbiotic relationship. There are several aspects concerning efforts in understanding al-Maqâshid asy-Syar'iyyah, namely analysis of the lafadz of commands and prohibitions, the study of commandments causes and prohibitions causes, analysis of the Shari'a silence 'attitude and the establishment of a law and an analysis of the objectives of ashliyah and thabi'ab of all the laws that have been established by Shari'. ${ }^{23}$

In its application, the linguistic approach (textual approach) and the benefit approach (contextual approach) was used by most scholars in an effort to understand al-Maqâshid asy-Syar'iyyah. In addition, the role of maqashid as-syar'iyyah in the formation of law is very urgent and significant, including when there is no proof in the Qur'an or As Sunnah in

${ }^{23}$ al-Syâthibî, Al-Munâafaqât Fi Usbûli AsySyarỉah, Juz II, 298.

${ }^{24}$ Muhammad Mushtafa az-Zuhaili, Maqâshid Asy-Syariah al-Islamiyah (Maktabah Syamilah), n.d., 19.

${ }^{25}$ Abdul Kadir Muhammad, Hukum Dan Penelitian Hukum (Bandung: PT. Citra Aditya Bakti, 2004), 57. contemporary cases, the mujtahids use theory of al-Maqâshid asy-Syar'iyyah in istinbath law after combining with ijtihad, istibsan, istiblah, and so on. Besides this theory can also help mujtahid to restore a law related to the act of a servant so as to produce laws that are in accordance with the conditions of society. ${ }^{24}$

\section{METHOD}

This research is a normative juridical research, which is namely a juridical research method with a systematic way of conducting a study. ${ }^{25}$ Peter Mahmud Marzuki explained, normative legal research is the process of finding a rule, principles, and legal doctrines to answer the legal issues at hand. ${ }^{26}$ This type of research is also called by "legal research" or "legal research instruction". ${ }^{27}$ This study uses legal material that is authoritative, namely Act Number 6 Year 2018 on Health Quarantine, Government Regulation Number 21 Year 2020 on LSSL in the framework of Accelerating Handling of Covid-19, and Minister of Health Regulation Number 9 year 2020 on LSSL Guidelines in the

26Peter Mahmud Marzuki, Penelitian Hukum (Jakarta: Kencana, 2010), 35.

${ }^{27}$ Soerjono Soekanto and Sri Mamudji, Penelitian Hukum Normatif Tinjauan Singkat (Jakarta: Rajawali Pers, 2006), 23. 
framework of Accelerating Handling of Covid-19.

The technique of collecting legal materials is done by library research on legal materials, ${ }^{28}$ namely by carrying out an inventory and identification of a number of statutory regulations, literature and other references that are related to the discussion in this study. The analysis technique used is content analysis which is an integrative analysis method and conceptually directed to find, identify, process and analyze legal material to understand its meaning, significance and relevance. ${ }^{29}$ The data analysis method is normative analysis, which is interpreting legal material based on norms, theories and legal doctrines related to the subject matter which are then reviewed from the perspective of alMaqashid asy-Syar'iyyah.

\section{RESULTS AND DISCUSSION}

The Policy of Large-Scale Social Restrictions (LSSL) in Indonesia

Corona Virus Disease 2019 (Covid19) has been declared by WHO as a pandemic and the Government of Indonesia based on Presidential Decree No.

${ }^{28}$ Mukti Fajar and Yulianto Achmad, Dualisme Penelitian Hukum: Normatif Dan Empiris (Yogyakarta: Pustaka Pelajar, 2010), 160.

${ }^{29}$ Burhan Bunging, Metodologi Penelitian Kualitatif: Aktualisasi Metodologi Ke Arah Ragam Varian Kontemporer (Jakarta: PT. RajaGrafindo Persada, 2007), 203.
11 of 2020 on Determination of Public Health Emergency Corona Virus Disease 2019 (Covid-19) has declared Covid-19 as a mandatory public health emergency Countermeasures were made, starting from 29 February 2020 to 29 May 2020 related to this virus pandemic with a total time of 91 days. Efforts in countermeasuring the public health emergency are carried out in the form of health quarantine measures, the one of which is health quarantine measures in the form of large-scale social restrictions. Article 1 of the Health quarantine Act explains that large scale social limitation are restrictions on certain activities of residents in an area suspected of being infected with a disease and / or contaminated in such a way as to prevent the possibility of spreading the disease or contamination. ${ }^{30}$

As for the goal of this LSSL as the Act, it is to prevent the spread of public health emergencies that occur between people in a certain area, ${ }^{31}$ so that the distribution chain of Covid-19 from person to person can be minimized till finally it is broken. Thus, in the end it will be shown in a decrease in positive cases of co-19. In the guidelines for implementing the LSSL, ${ }^{32}$ it is

${ }^{30}$ Act Number 6 of 2018 on Health Quarantine, Chapter I General Provisions, Article 1 Number 12.', 2018.

31'Act Number 6 of 2018 on Health Quarantine, Chapter I General Provisions, Article 59 Pharagraph (2)', 2018.

32 'Attachment of Minister of Health Regulation No. 9 of 2020 on Guidelines of Large Scale Social Limitation in the Framework of Handle 
emphasized that the implementation of the LSSL is carried out during the longest incubation period (14 days). If there are still reports that are published containing new ones, it can be extended within 14 days of the discovery of the last case.

In the policy Government concerning the Policy of LSSL, the discussion of the matter that became the focus of the author is regarding some of the implementation provisions in the Guidelines for Large Scale Social Limitation in the Framework of Accelerating Handling Covid-19 stipulated by Minister of Health Regulation No. 9 of 2020, namely: ${ }^{33}$

1. Dismissing Schools

Dismissing the schools in the provisions of the LSSL is the termination of the teaching and learning process in schools and replacing them with teaching and learning processes at home with the most effective media. In addition, it also imposed restrictions on the activities of all educational, training, research, coaching, and similar institutions, while still being able to carry out the learning process through the most effective media by prioritizing efforts to prevent the spread of disease. But exceptions for educational institutions, training, and research related to health services.

\section{Dismissing The Workplaces}

The purpose to dismiss the workplace is namely tha the work process at work and replace it with work processes at home/residence, to increase worker productivity. This provision is also excluded for certain offices or entities that provide services related to public order and security, food needs, fuel oil and gas, health services, economy, finance, communication, industry, exports and imports, distribution, logistics, and needs other basic.

\section{Restrictions on Religious Activities}

Restrictions on religious activities in the LSSL stipulate that religious activities carried out at home and attended by families are limited, by keeping everyone away, all places of worship then must be closed to the public. In the case of the funeral of a person who died not because of Covid-19 with a number of those present not more than twenty people can be permitted by prioritizing efforts to prevent the spread of disease (breaking the chain of transmission). These rules are not absolute, because there are exceptions to the religious activities which are guided by statutory regulations, and fatwas or views of official religious institutions recognized by the government.

33 Ibid. 
4. Limitation of Activities in Public Places or Facilities

Limitation of activities in public places or facilities in the form of restrictions on places or public facilities by taking into account the fulfillment of the basic needs of the population, so that there are some excluded places such as markets, shops, or places for selling drugs and medical equipment, food needs, basic necessities , fuel oil, energy and others, as well as health service facilities or other facilities in the context of fulfilling health services. The exception is carried out with due regard to crowd restrictions and is guided by protocols and regulations.

5. Restrictions on Social and Cultural Activities

Restrictions on social and cultural activities carried out in the form of a ban on the crowd of people in social and cultural activities and guided by the views of official customary institutions recognized by the government and legislation. This includes all political, sports, entertainment, academic and cultural associations or meetings.

6. Restrictions on Moda-Transportation

Restrictions on this aspect includes transportation that transports passengers, transportation that transports goods, transportation for fire services, law and

${ }^{34}$ Ibid.

${ }^{35} \mathrm{CNN}$ Indonesia, 'Mengenal Social Distancing Sebagai Cara Mencegah Corona', News, Cnnindonesia.Com, (14 March 2020), order services, but emergency services and train operations, airports and seaports, including airports and seaports of the The Indonesian National Armed Forces or The Indonesian National Police, for movement cargo, aid and evacuation, and related operational organizations continue to run. This large-scale social restriction also emphasized that it would have an impact on the limitation of space for all communities in the region, so that Covid-19 countermeasures in emergency situations can be effective. However, it must still prioritize the safety and interests of the society both at national and regional levels. ${ }^{34}$

The Review of the al-Maqashid asySyar'iyyah theory about Large Scale Social Limitation (LSSL) in Indonesia

In the LSSL implementing, technically there is a need for everyone to be implemented as determined by the Government, in an effort to tackle this extraordinary pandemic outbreak, one of which is to socialize the social distancing movement. This concept explains that in order to reduce or even break the Covid-19 infection chain a person must maintain a safe distance from other humans at least 2 meters, and not make direct contact with others, avoiding people gatherings. ${ }^{35}$ With

https://www.cnnindonesia.com/gayahidup/2 0200314102823-255-483358/mengenal-socialdistancing-sebagai-caramencegah-corona. Accessed on May 9th 2020. 
this concept, it certainly hinders the process of communication and even hinders the implementation of collective worship (pilgrims) and hospitality has been a culture of Indonesian Muslim society since hundreds of years ago.

Considering the condition of the pandemic out break Covid-19 crisis has troubled you Muslims in carrying out their worship activities, the Indonesian Ulema Council (IUC) on March 16, 2020 issued a fatwa that incorrectly stipulated its legal provisions stating that everyone must carry out efforts to protect their health and avoid everything which can cause exposure to disease, because it is part of maintaining the main goal of religion (adh-Dharuriyat alKhams)..$^{36}$ The fatwa supports LSSL policy that have been set by the Government, so that activities are more focused at home, both in terms of worship, work, and transactions.

Then, to consider that health law enforcement in the current condition of the pandemic outbreak Covid-19 has affected all aspects of Indonesian people's lives, especially in terms of the welfare of a Muslim's soul, where he must meet the

36Indonesia Ulema Council, 'Fatwa of Indonesia Ulema Council No. 14 of 2020 on Organizing Worship in Outbreak Situations of Covid-19'.

${ }^{37}$ Nathan Mascaro and David H. Rosen, 'The Role of Existential Meaning as a Buffer against needs of outwardly and also the needs of psychologically, both of which cannot be separated or priority to each other. According to the author though, an important concept in maintaining the welfare of the soul is spirituality, that is, how a person sees his life as having coherence and purpose, also gaining personal experience through the power he believes to be an ecompassing, transcending or underlying life. ${ }^{37}$

By using spirituality as a coping mechanism through intense difficult times is correlated with higher levels of hope, optimism, and positive life outcomes. ${ }^{38}$ Thus difficult period this can be passed with a stable spiritual condition, and surely the purpose of the Shari'a is to be reduced so that one's lahiriyah and inner condition remain stable. The author considers that from this outbreak we can also understand what is actually desired by Shari'at (through al-Maqashid asy-Syar'iyyah), whether we should continue to worship, work and carry out activities normally while having to sacrifice our own health and even eliminate our own lives. Surely this is not the purpose of the Shari'ah, because Allah

Stress', Journal of Humanistic Psychology 46, no. 2 (2006): 168-190.

38 Susana C. Marques, Shane J. Lopez, and Joanna Mitchell, 'The Role of Hope, Spirituality and Religious Practice in Adolescents' Life Satisfaction: Longitudinal Findings', Journal of Happiness Studies 14, no. 1 (2013): 251-261. 
wants his servants to live well so that he can worship Him.

Actually, the role of al-Maqashid asySyariyyah in the formation of law is very urgent and significant, especially in contemporary issues like today. Of course, IUC has used al-Maqashid asy-Syar'iyyah in the term of law with its fatwa, after combining it with ijtibad, istibsan, istiblah, and so on. The theory of al-Maqashid asySyar'iyyah in an emergency condition like this is very helpful for a mujtahid to show a law related to the actions of a servant so as to produce a law in accordance with the conditions of society. ${ }^{39}$

In principle, most scholars use the linguistic approach (textual approach) and the benefit approach (contextual approach) in an effort to understand al-Maqashid asySyar'iyyah. In addition, there are several aspects in understanding al-Maqashid asySyar'iyyah, namely the analysis of lafadz commands and prohibitions, the study of 'divine commandments and' divine prohibitions, analysis of the Shari'ah silence 'attitude and the establishment of legal matters and analysis of the objectives of ashliyah and thabi'yyah of all the laws that have been established by Shari'..$^{40}$ All of this certainly did not escape the consideration of the IUC in issuing a fatwa related to the
Covid-19 pandemic outbreak. Therefore, according to the Author, following the LSSL process well is an effort to maintain life, the implications of which will still be able to worship to Allah, it's just that the aspects of worship procedures are slightly different from the habits.

Regarding the LSSL rules by facilitating schools and workplaces, there must be consequences. Although the purpose of school consolation in the provisions of this LSSL is to stop the teaching and learning process in schools and replace it with the teaching and learning process at home with the most effective media. Then the purpose of the workplace relaxation is to limit the process of working at work and replace it with the process of working at home/residence, to maintain employee productivity/ performance. However, there are several places and aspects of schools and workplaces that are excluded by the Government, bearing in mind that the process of governance at the central and regional levels must also continue. Educational needs and the need for employment is a requirement that is not possible to be ruled out. Therefore, through of LSSL the activity is not stopped, it is limited only by the people, their working hours, and the place and scope. For

\footnotetext{
${ }^{39}$ Muhammad Mushtafa az-Zuhaili, Maqâshid Asy-Syarîab al-Islamiyah (Maktabah Syamilab), ${ }^{40}$ al-Syâthibî, Al-Muwâfaqât Fi Usbûli Asyn.d., 19.

Syarỉah, Juz II.
} 
example the limitation of religious activities in the LSSL is regulated that religious activities carried out at home and attended by families are limited, by keeping everyone away, then all places of worship must be closed to the public. Then restrictions on social and cultural activities are also implemented in the form of a ban on the crowd in social and cultural activities. This includes all political, sports, entertainment, academic and cultural associations or meetings.

In addition, the limitation of activities in public places or facilities in the form of restrictions on public places or facilities by taking into account the fulfillment of the basic needs of the population, so that there are some excluded places such as markets, shops, or places for selling drugs and medical equipment, food needs, staple goods, fuel oil, energy and others, as well as health service facilities. One of the limitations becomes polemic is the limitation of the moda of transportation, which with this limitation has reduced income and even harmed many businessman and breadwinners such as drivers and ojegs.

Of the various restrictions set forth through the LSSL above, according to the author, is an appropriate preventive effort, without ignoring the negative impacts, because that is the best choice at this time for a government where our country does not have the ability to carry out lockdown in full.

However, the goals of these restrictions are for the safety of people, social and economic Indonesia safety, which the author considers to have fulfilled the category of primary needs that must be guarded, maintained and carried out by a Muslim, which in al-Maqashid asy-Syar'iyyah's theory is a dharurah condition. The opinion of this writer is in line with the opinion of al-Juwaini, ${ }^{41}$ that one of the pillars of alMaqashid asy-Syar'iyyah is based on something that can be reasoned and understood its meaning so that it is interpreted to be a primary (dharurat), he pointed out as qisas sanctions prescribed to avoid humans from continuous bloodshed. In addition, the author believes that the implementation of the LSSL is also in accordance with the theory of al-Maqashid asy-Syar'iyyah with the perspective of the role and function of a mashlahah towards the survival of beings. ${ }^{42}$

The condition of the Pandemic Outbreak Covid-19 requires Muslims to be at home whether for worship, work or activities having fulfilled the category of

\footnotetext{
${ }^{41}$ Al-Juwaini, Al-Burban Fi Ushul Figh, al-Wafa' Juг II.
} 
Maqashid Dharuriyyat, which means urgent or emergency needs. So that the dharuriyyat needs, if these needs are not met, it will threaten the safety of the Muslims in Indonesia. ${ }^{43}$ These categories include Hifdz ad-Din (Preserving Religion), Hifdr an-Nafs (Preserving the Soul), Hifdr al-'Aql (Preserving Intellect), Hifdz, an-Nasb (Preserving Descendants), and Hifdr al-Mal (Preserving the Soul), and in principle, Islamic Shari'ah was revealed to maintain the five main points.

\section{Abbreviations and Acronyms}

LSSL: Large Scale Social Limitation, IUC: Indonesian Ulema Council, Covid-19.

\section{CONCLUSION}

The overwhelming of the Covid-19 pandemic outbreak in Indonesia requires the Government to impose the LSSL in which the policy raises many new problems, including in the case of congregational worship and friendship that is already entrenched in Indonesia. However, seeing the urgency as an effort to save the lives of the society including Muslims in Indonesia, the LSSL policy that was determined although it had a significant impact, was the best choice that must be taken by the Government and Indonesia people.
From the viewpoint of the alMaqashid asy-Syar'iyyah theory, the concept of applying LSSL is Maqashid Dharuriyyat, where this category requires prioritizing efforts in order to save and maintain the five main points in reconciliation, namely: preserving religion, preserving souls, preserving mind, preserving offspring and preserving Treasure.

It is hoped that the society of Indonesian Muslim will be able to follow the LSSL process well and be able to worship at home, work and carry out activities from home.

\section{REFERENCES}

'Act Number 6 of 2018 on Health Quarantine, Chapter I General Provisions, Article 1 Number 12.', 2018.

'Act Number 6 of 2018 on Health Quarantine, Chapter I General Provisions, Article 59 Pharagraph (2)', 2018.

Ahmad, Amrullah. Dimensi Hukum Islam Dalam Sistem Hukum Nasional. Jakarta: Gema Insani Press, 1996.

Al-Juwaini. Al-Burban Fi Ushul Figh, alWafa' Juz II. Tahqiq: Abd al-Ajim, 1918.

'Attachment of Minister of Health Regulation No. 9 of 2020 on Guidelines of Large Scale Social Limitation in the Framework of Handle Accelerating of Corona Virus Disease 2019 (COVID-19)', 2020.

Bahri, Syamsul. Metodologi Hukum Islam, Cet. I. Yogyakarta: Teras, 2008.

Bayhaqi, Ahda. 'Virus Covid-19 Diprediksi Mulai Masuk Indonesia Pada 
Januari 2020'. News. Merdeka.Com, May 2020 .

https://www.merdeka.com/ peristiwa/ virus-covid-19diprediksi-mulai-masuk-indonesiapada-januari-2020.html.

Bunging, Burhan. Metodologi Penelitian Kualitatif: Aktualisasi Metodologi Ke Arab Ragam Varian Kontemporer. Jakarta: PT. RajaGrafindo Persada, 2007.

CNN Indonesia. 'Mengenal Social Distancing Sebagai Cara Mencegah Corona'. News. Cnnindonesia.Com, 14 March 2020. https://www.cnnindonesia.com/g ayahidup/20200314102823-255483358/mengenal-socialdistancing-sebagai-caramencegahcorona.

Dewi, Fitri Sartina. 'Pedoman PSBB Corona Terbit, Ini Isi Lengkapnya'. Berita. Kabar24.Bisnis.Com, 4 April 2020. https://kabar24.bisnis.com/ ead/20200404/15/1222527/ pedoman-psbb-corona-terbit-iniisi-lengkapnya.

Djazuli, A. Fiqh Siyasah. Bandung: Prenada Media, 2003.

Fajar, Mukti, and Yulianto Achmad. Dualisme Penelitian Hukum: Normatif Dan Empiris. Yogyakarta: Pustaka Pelajar, 2010.

Hukumonline.com. 'Menkes Terbitkan Aturan Pedoman PSBB Penanganan Covid-19'. News. Hukumonline.Com, May 2020. https://www.hukumonline.com/b erita/baca/ lt5e88 b1c22a471/ menkes-terbitkan-aturanpedoman-psbb-penanganan-covid$19 /$.

Indonesia Government. 'Government Regulation No. 21 of 2020 on Large Scale Social Restrictions in the Framework of Accelerating Handling of Corona Virus Disease 2019 (Covid-19) Article 1', n.d.

Indonesia Ulema Council. 'Fatwa of Indonesia Ulema Council No. 14 of
2020 on Organizing Worship in Outbreak Situations of Covid-19', n.d.

Lihasanah, Ahsan. Al-Fiqh al-Maqâsid Inda al-Imami Asy-Syâthibi. Egypt: Dar alSalam, 2018.

Mandzur, Ibnu. Lisaan Al-'Arab. Kairo: Darul Ma'arif, n.d.

Marques, Susana C., Shane J. Lopez, and Joanna Mitchell. 'The Role of Hope, Spirituality and Religious Practice in Adolescents' Life Satisfaction: Longitudinal Findings'. Journal of Happiness Studies 14, no. 1 (2013): 251-261.

Marzuki, Peter Mahmud. Penelitian Hukum. Jakarta: Kencana, 2010.

Mascaro, Nathan, and David H. Rosen. 'The Role of Existential Meaning as a Buffer against Stress'. Journal of Humanistic Psychology 46, no. 2 (2006): 168-190.

Muhammad, Abdul Kadir. Hukum Dan Penelitian Hukum. Bandung: PT. Citra Aditya Bakti, 2004.

Qardhawi, Yusuf al-. Fiqih Praktis Bagi Kebidupan Modern. Kairo: Makabah Wabah, 1999.

Raisuni, Ahmad ar-. Naz̧hariyyât AlMaqâshid Inda Asy-Syâthibi. Rabat: Dâr al-Amân, 1991.

Soekanto, Soerjono, and Sri Mamudji. Penelitian Hukum Normatif Tinjauan Singkat. Jakarta: Rajawali Pers, 2006.

Syâthibî, Abu Ishâq al-. Al-Muwâfaqât Fi Ushûli Asy-Syarîah, Juz II. Beirut: Dar al-Kutub al-Ilmiyah, 2003.

Task Force for the Acceleration of Handling Covid-19. 'Data Sebaran, Update Terakhir per 09 Mei 2020'. News. Covid19.Go.Id, May 2020. https://covid19.go.id/.

Umar, Hasbi. Nalar Fiqib Kontemporer. Jakarta: Gaung Persada Press, 2007.

W, Yoseph Hary. 'Hasil Penelitian 3 Transmisi Virus Corona Sampai Ke Indonesia, Ini Asal Muasal COVID-19 Di Tanah Air'. News. Jogja.Tribunnews.Com, 6 May 2020. https://jogja.tribunnews.com 
/2020/05/06/hasil-penelitian-3transmisi-virus-corona-sampai-keindonesia-ini-asal-muasal-covid-19di-tanah-air?page $=4$.

Zein, Satria Effendi M. Metodologi Hukum Islam Dalam Amrullah Ahmad, Dkk,
"Dimensi Hukum Islam Dalam Sistem Hukum Nasional. Jakarta: Gema Insani Press, 1996.

Zuhaili, Wahbah al-. Ushûl Al-Fiqh al-Islâmi. II. Damaskus: Dâr al-Fikri, 1986. 